\title{
Enhancing Students' Speaking Skills through Debate Techniques
}

\author{
${ }^{1}$ Evan Afri, ${ }^{2}$ Ely Ezir Marpaung, ${ }^{3}$ Intan Maulina \\ Politeknik Ganesha Medan, Universitas Asahan, Universitas Efarina \\ evanafri@gmail.com
}

Submitted: 07/ Agustus/2021

Received: 10/ Agustus /2021

Published: 11/ Agustus /2021

\begin{abstract}
Speaking is considered an essential skill to master. There are some problems with students, lack of communication in class, and lack of vocabulary. The purpose of this study was to improve students' speaking skills through debate techniques. This research method is classroom action research, which is used in two cycles, and each cycle has four steps: planning, action, observing, and reflection. The data presented in this study were obtained from observations, interviews, and students' speaking scores. In this study, the researcher got the result, namely the percentage of speaking. Scores in cycle one $71 \%$ passed, and $29 \%$ failed; $92 \%$ and $8 \%$ failed in cycle two. So, the increase in yield in cycle 1 and cycle 2 is $21 \%$. Based on the data above, it can be concluded that learning English, especially speaking through debate techniques, can improve students' speaking skills.
\end{abstract}

Keywords: classroom action research, speaking skills, debating techniques.

\section{Introduction}

Speaking is an essential tool for communicating, thinking, and learning. For communication, students must master speaking elements such as vocabulary, pronunciation, grammar, comprehension, and fluency. That's how improving students' speaking skills are always a concern in class. Speaking is critical because by mastering speaking skills, people can have conversations with others, give ideas, and exchange information. Speaking is using language with a familiar voice, speaking words, knowing and using language, expressing oneself in words, making speeches.

However, the observations at Politeknik Ganesha Medan show that the students have some problems with speaking skills. The students are less communicative in class; they feel not confident speaking English.

Because they are afraid of making mistakes in composing sentences, the students lack vocabulary; they are lazy to learn English, so the students don't have enough language to use when they have to practice English.

Teaching speaking through debate technique has succeeded in improving speaking skills, which is compatible with previous research. The debate is very interested in being applied to improve speaking skills. Students have many opportunities to practice speaking and to be actively involved in the discussion. However, they work very cooperatively and try to defend their team, and they are more active in speaking in class (Arung, 2016). Furthermore, debates and peer assessments make it possible to increase students' self-confidence and motivation (Umar, 2016).

Speaking is one of the fundamental language skills to be mastered by students to become good communicators. Speaking is the use of language verbally to communicate with other people.

(Fulcher, 2003). To speak is to use language in a familiar voice; say the words; know and be able to use language; express oneself in words; make a speech (Hornbry, 1987). Another expert 
(Theodore, 1960) said speaking is a skill used by a person in daily communication both at school and outside.

Based on these statements, the writer can conclude; speaking can be a way to convey feelings through words in conversation with others. It means that humans use words and phrases in the interactive process of constructing the meaning of speaking.

As a solution, the debate is an effective speaking activity that encourages students to improve their communication skills. Debate is about actual or simulated problems. The learner's role ensures that they have sufficient shared knowledge of the issue and a range of opinions or interests to defend. At the end of the activity, they may have to reach a concrete decision or vote (William, 1981). Debate is a formal discussion, consideration of a problem, a formal presentation of opposing ideas". Further added, it is a great way to improve speaking skills and is very helpful in providing experience in developing convincing arguments. (Rofl, 2009).

\section{The Role of Speakers in Debate Techniques}

According to (Christoper, 2014), there are several roles of speakers in debating techniques. They are:

1. PROP: (a) Define the motion, i.e., the first PROP speaker opens the debate. They must first define the motion; (b) Finding debate, it almost always proves helpful to focus only on certain areas, as it will be very difficult to solve a single problem at a global level; (c) Presenting the case and team outline, the first speaker will establish the PROP case framework, explaining and justifying what they stand for, but for other motivations as well. Then he would put forward the arguments they would talk about; (d) The first argument, the first speaker presents the case, and the first two arguments, starting with the most important because it will be the most debated.

2. First OPP: The first OPP speaker's job is to agree or disagree with the wording definition of the motion. The framework established by defining motions is a term that will continue to be debated.

3. Second PROP: Since there is usually only one more argument to present, Second PROP is expected to use about half of the speech refuting what First OPP said and what he missed saying. There must be at least one more argument.

4. Second OPP: Since there is usually only one more argument to present, Second OPP is expected to use about half of the speech to refute what First PROP and Second PROP are saying. There must be at least one more argument.

5. Third PROP: The third PROP will only refute what has been said on the part of OPP. There are no more arguments in the third speech. One should not forget to constantly connect argument lines to the case frame over and over again. Third speakers don't need to do as much research as first and second speakers do, at least not for the sake of their speech.

6. OPP and PROP counter-speech: Reply speeches mean to take a significant step back and look at the debate from the point of view. Trying not to argue and just pointing out areas of contention is often a thin red line that, in some cases, can't be avoided crossing..

However, the purpose of the counter speech is to give each team another chance to take a more philosophical approach to the contentious clash.

\section{Research Methodology}

In this study, the researcher used classroom action research which is a type of qualitative method. From getting the data, the researcher wants to describe and explain the problem chosen in this study. Classroom action research uses two cycles, and each process consists of four steps. plan, act, observe and reflect

The data source for this research is in third-semester students of Politeknik Ganesha Medan. The results of the data will be described using qualitative data, and the researcher used observation, interview, and test. The data analysis technique comes from the interpretation of data 
collection. Researchers have obtained data from documents, observed the teaching and learning process, and student test results in all data. There are three steps to perform data analysis techniques: data reduction, data description, data verification.

This study uses triangulation for the validity of data collected from observations, interviews, and speaking tests. Successful research criteria mean that students can pass the minimum score standard (KKM). In this study, the researcher will set a target of $100 \%$ of students passing the KKM. These are collected from the indicator stage, essential competencies, and standard competencies to become the minimum score standard or KKM (70).

\section{Research Results And Discussion}

\section{Pre-Action}

Preliminary research begins by interviewing English teachers. According to the teacher, some students are good in English, but the researcher found that several percent of students are low in English, so it is not uncommon for students to become passive learners in each class. Problems faced by students in learning English. The students are less communicative in class; they feel not confident speaking English. Most of the students are afraid of making mistakes in composing sentences. The students lack vocabulary; they are lazy to learn English, so they don't have enough language to use when they have to practice English.

\section{Cycle 1}

In the first cycle, the researcher explained the material to students about asking and giving opinions, asking several topics, and the researcher invited students to express their views. Then the researcher explained the rules of the debate. Rules are an essential part of the debate; they tell us how to debate. Every speaker or student should know what they are going to do. It makes students understand the ways or rules of discussing motions. So, it is easy for students to take part in teaching and learning activities in the debate. The researcher arranged the students into several groups. Each group consists of three students to make the discussion more effective and efficient. Then the researcher divided the team into affirmative and opposing teams. The researcher gave several motions for debate; here is the debate motion: The school must prohibit students from bringing cell phones to school. Having a boyfriend/girlfriend increases student achievement. That using motorbikes for students should be banned.

Public schools are better than private schools. Motions should be discussed as best as possible by the team before the debate starts; they should prepare an outline to present their team's argument or point of view when they argue. Researchers gave the team 15 minutes to build a movement system and allowed students to present their arguments and start the debate in order. The discussion continues until all members have given their opinion. After the first group of disputes was over, the researcher asked the second group to show the class how to start their debate, followed by the last group. After all, groups practiced their discussion, the researcher reviewed and evaluated the activity.

Based on the observations, several things were seen: The students paid attention to the activities in class. Students enthusiastic in the learning process are pretty good, but their speaking skills are still low. The students did not have enough vocabulary to express their arguments. Some students are still shy to speak in front of their friends. Based on the collaborator's observation sheet, $88 \%$ of students are cooperative, $92 \%$ are confident, $75 \%$ are enthusiastic, and $84.5 \%$ are active.

From the students' speaking practice scores based on the minimum standard score (70) there were 17 students $(71.83 \%)$ who could achieve the target, and there were 7 students $(29.17 \%)$ who failed to reach the minimum score target.

\section{Cycle 2}

The researcher explains how to express agreement and disagreement by presenting some expressions about it. The teacher asks students to agree and disagree. Then the teacher arranges 
the students into several groups. The group is different from before, so it doesn't make students bored. Each group consists of three students to make the debate more effective and efficient. Next, the researcher divided the team into affirmative and opposing teams. Researchers provide a motion that will be debated. The debate motion: That this House supports the death penalty for corruptors. Schools should prohibit students from taking part-time jobs so that the government will not use the national exam for graduation standards and give the death penalty to drug dealers. The teacher asks students to sit in groups. The teacher asks students to outline the motion; it takes about 15 minutes. Each group outlines; it is essential because it builds their case building. The researcher allowed students to present their arguments and start the debate in order. The discussion continues until all members have given their opinion. After the first group of disputes was over, the researcher asked the second group to show the class how to start their debate, followed by the last group. In the second cycle, the students looked happy and dared to argue and argue. The teaching and learning process in the debate was closed by making joint conclusions. The conclusion is to find some problems encountered during learning to speak through the debate technique.

Based on the activities in cycle two, the data showed that the students increased their English competence. Most of the students are active enough to talk. They find their motivation to work hard effectively. When the debate was conducted, the students followed this learning process and felt happy with the lesson. In cycle 2, students can work together with each team, other groups, and researchers. They provide opinions, ideas, and points of view regarding the motions submitted. They pay attention to the researcher's instructions, to the achievements of other students, and also they give different opinions through the opinions of other teams. All students pay attention to each other. Based on the observation sheet, $96 \%$ are cooperative, $100 \%$ are confident, $92 \%$ are enthusiastic, and $86 \%$ are active. Although students can improve their speaking scores, some students still fail to reach the target score. From the practice scores of students based on the standard minimum score (70), there are 22 students (92\%) who can achieve the target, and there were 2 students $(8 \%)$ who could not reach the minimum score target.

\section{Observation Results}

In teaching speaking using debate techniques, students have more opportunities to speak in a team; they can share opinions or arguments in debates. This finding is supported by the debate theory, which states by William, "Debate is about real or simulated problems. The learner's role ensures that they have sufficient shared knowledge of the issue and a range of opinions or interests to defend. At the end of the activity, they may have to reach a concrete decision or issue this issue".

\section{Test results}

The students' speaking test results show that debate techniques can improve students' speaking skills. The researcher concluded by analyzing the percentage of students who pass the KKM. After the research was conducted in the first cycle there were $71.83 \%$, and in the second cycle there were $92 \%$ of students who passed the KKM. 


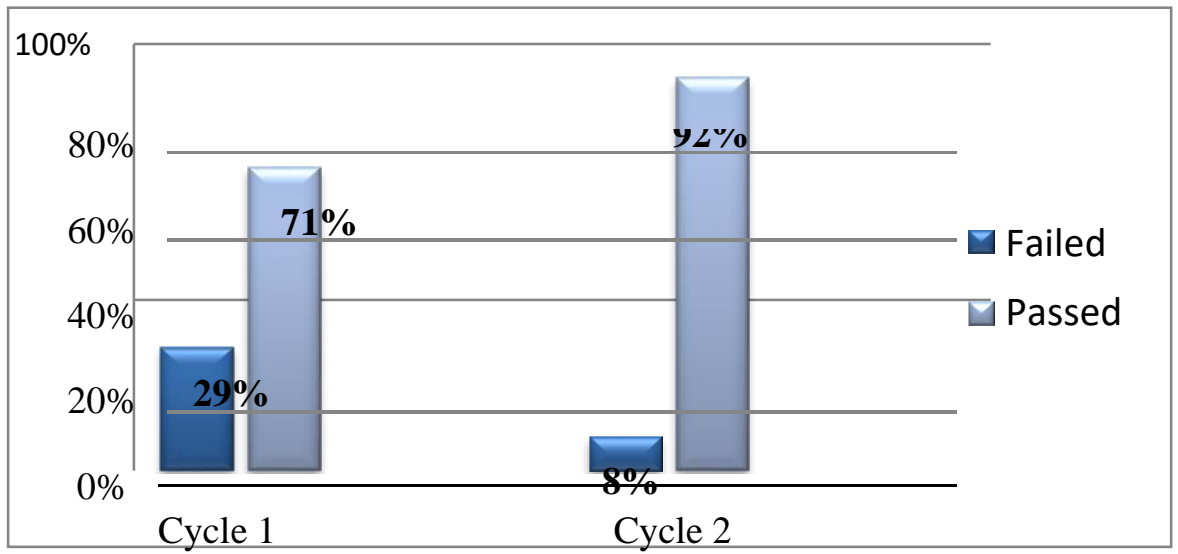

\section{Picture 1. Percentage of Student Success in Cycles 1 and 2}

The researcher concludes that the debating technique can improve students' speaking skills based on all the data. According to Arung Fernandes, "The debate is fascinating to be applied to improve speaking skills. Students have many opportunities to practice speaking and to be actively involved in the debate. However, they work very cooperatively and try to defend their team, and they are more active to talk in class." The activeness of all students shows this after participating in the lesson.

\section{Interview results}

According to the interview results, Students show several responses; there are positive and negative responses. The students said that the debate was interesting. They can improve their speaking skills because argument makes them brave and confident to speak English. According to Fauzan, "Debates and peer-assessment make it possible to increase students' self-confidence and also their motivation." However, some students feel bored and nervous when implementing debates, and their speaking skills are still low.

\section{CONCLUSION}

After researching teaching English speaking in senior high schools, it can be shown that debate techniques can improve students' speaking skills. The students achieved some improvements not only in their academic scores but also in their behavior during the learning process. Students are confident and not shy to express their arguments. They enjoy and focus on joining the teaching and learning process and are more active, enthusiastic, confident, cooperative to take part in the learning process.

Based on the scores achieved by students. There is a significant improvement. This is evidenced by the increasing student test scores in each cycle. In cycle 1 the total number of students who passed the minimum score was 17 people, equal to $71 \%$. In cycle 2 the absolute and percentage of students increased. That's 22 People, equivalent to $92 \%$. It was higher than cycle 1 -research due to limited time for research. So the researcher ended the investigation after the cycle with $92 \%$ of the research target, namely $100 \%$. It means that twenty-two of the total students passed the minimum score, and the remaining two people, equal to $8 \%$, almost reached the minimum score indicated by the school; in other words, they failed.

The students showed various responses after using the debate; There were positive and negative responses. Still, in general, the students said that the debating technique was fun and helped improve their speaking skills. So the conclusion is that debate can improve students' speaking skills after they are taught through debate techniques. It can be a consideration for English teachers to organize the learning process. 


\section{REFERENCES}

Arung, Fernandes. Improving the Students' Speaking Skill through Debate Technique.JEE. Vol. 1, No. 1, March 2016

Umar, fauzan. Enhancing Speaking Ability of EFL Students through Debate and Peer Assessment.EFL. Vol. 1 No. 1, 2016

Fulcher, Gleen. Testing Second Language Speaking. (London: Pearson Education Limited, 2003) Hornby, A S. Oxford Advanced Learners' Dictionary of Current English, $6^{\text {th }}$ Ed.

New York: Oxford University Press, 1987

Huebner, Theodore. Audio Visual Technique in Teaching Foreign Language. New York: Cambridge University Press, 1960

Littlewood, William. Communicative Language Teaching. Cambridge: Cambridge University Press: 1981

Pritchard, Rofl. The Step by Step Guide to Debate. SEDA, Saskatchewan, Canada: 2009

Sanches, Christopher. A Quick Introduction to Debating in School, (Debating society Germany e.V.Max-Born-Gymnasium, Backnang. 2012-2014), P.13-16. 